PENELITIAN

\title{
Efektivitas Lidokain Intravena untuk Mengurangi Nyeri pada Pemberian Drip KCl melalui Akses Vena Perifer
}

\section{The Effectiveness of Intravenous Lidocaine in Decreasing Pain during Potassium Chloride Infussion from Peripheral Venous Access}

Kamala Kan Nur Azza ${ }^{\varpi}$, Noor Alia Susianti, Rizki Puji Agustin, Uswathon Khasanah, Lina Andarwanti, Widia Yuniatun

Instalasi Anestesiologi dan Terapi Intensif, RS Akademik UGM Yogyakarta, Indonesia

${ }^{凶}$ Korespondensi: kamalakan99@gmail.com

\begin{abstract}
Background: Hypokalemia is common electrolite imbalance. Severe hypokalemia can be life threatening. The correct and fast correction can be life saving. One of the intervention is administration of potassium chloride ( $\mathrm{KCl}$ ) from peripheral venous access, but $\mathrm{KCl}$ is so irritative that cause pain. To decrease pain is by adding lidocaine. Lidocaine is anasthethic agent that can be administrated intravenously and has alnalgetic effect.

Objective: To know the effectivity of lidocaine to reduce pain during $\mathrm{KCl}$ infusion from peripheral venous access.

Methods: This research was double blind randomized controlled trial. There were 37 hypokalemia patients who needed potassium correction. Patients were divided into 2 groups, 21 patients were allocated in the experimental group (lidocaine) and the others were in control group (without lidocaine) and pain scoring was using numeric pain rating scale in the middle (2,5 hour) and in the end (5 hour).
\end{abstract}

Result: There were no different characteristics between two groups in the early study. Lidocaine administration was proved to decrease pain occurance during correction process, both in the middle and in the end $(\mathrm{p}<0,05)$. For pain progressivity, lidocaine could prevent pain occurance in the first 2,5 housr $(\mathrm{RR}=0,47$, CI 95\% 0,26-0,85, p<0,05) however pain progressivity in the next 2,5 hour was not statistically significance ( $\mathrm{RR}=0,95$, CI 95\% 0,30-2,99, $\mathrm{p}>0,05)$.

Conclusion: Lidocaine decrease pain sensation during potassium correction process so can be considered to be aplicated in clinical practice.

Keywords: lidocaine; numeric pain rating scale; pain; peripheral venous; potassium chloride infussion

Volume 12, Nomor 1, Tahun 2020 


\begin{abstract}
ABSTRAK
Latar Belakang: Hipokalemia merupakan gangguan elektrolit yang sering terjadi. Hipokalemia berat dapat mengancam jiwa. Koreksi hipokalemi yang tepat dan cepat dapat mencegah komplikasi yang membahayakan jiwa. Salah satu intervensi yang dapat dilakukan adalah dengan pemberian $\mathrm{KCl}$ melalui akses vena perifer, tetapi $\mathrm{KCl}$ memiliki sifat iritatif yang dapat menyebabkan nyeri. Cara yang dapat dilakukan untuk mengurangi nyeri adalah dengan pemberian lidokain intravena. Lidokain merupakan obat anestesi yang dapat diberikan secara intravena dan memberikan efek analgesia.
\end{abstract}

Tujuan: Mengetahui keefektifan lidokain untuk mengurangi nyeri pada pemberian $\mathrm{KCl}$ melalui akses vena perifer.

Metode: Penelitian ini merupakan uji klinis randomisasi samar berganda melibatkan 37 pasien hipokalemia yang memerlukan koreksi. Pasien terbagi menjadi 21 pasien kelompok perlakuan (mendapatkan lidokain saat koreksi) dan 16 pasien kelompok kontrol (tanpa lidokain) yang kemudian penilaian nyeri menggunakan numering pain rating scale (NPRS) pada pertengahan proses koreksi (2,5 jam) dan akhir koreksi (5 jam). Hasil: Tidak terdapat perbedaan karakteristik dasar di kedua kelompok pada awal penelitian. Pemberian lidokain terbukti dapat mengurangi terjadinya nyeri dari proses koreksi kalium pada pertengahan proses koreksi dan akhir proses koreksi $(p<0,05)$. Pada progresivitas nyeri, pemberian lidokain mampu mencegah terjadinya nyeri pada 2,5 jam pertama $(\mathrm{RR}=0,47,95 \% \mathrm{IK} 0,26-0,85, \mathrm{p}=0,01)$ namun progresivitas nyeri 2,5 jam berikutnya tidak bermakna secara statistik $(R R=0,95,95 \%$ IK $0,30-2,99, p>0,05)$.

Kesimpulan: Lidokain dapat mengurangi nyeri selama proses koreksi kalium sehingga dapat dipertimbangkan untuk diaplikasikan dalam praktik klinis.

Kata Kunci: drip kcl; lidokain; numeric pain rating scale; nyeri; vena perifer

\section{PENDAHULUAN}

Kalium merupakan salah satu elektrolit yang memiliki peranan penting dalam tubuh. Kalium merupakan ion bermuatan positif yang berada di dalam sel yang mengatur fungsi sel agar dapat berjalan dengan normal. Kadar kalium normal dalam serum atau plasma orang dewasa adalah 3,5-5,1mEq/L. Kadar normal kalium yang normal ini dipengaruhi oleh keseimbangan dari asupan kalium perhari $(100 \mathrm{mEq} /$ hari $)$ dan ekskresi dalam urin $(90 \mathrm{mEq} / \mathrm{hari})$ dan feses $(10 \mathrm{mEq} / \mathrm{hari})$. Selain itu, distribusi kalium di dalam otot, tulang, liver, sel darah merah, dan cairan ekstraseluler juga berperan dalam menjaga keseimbangan kadar kalium dalam tubuh. ${ }^{1,2,3}$

Adanya gangguan pada asupan kalium, proses ekskresi kalium, dan pergeseran kalium transelular (trancellular shift) akan sangat berpengaruh pada kadar normal kalium di dalam tubuh. Saat asupan kalium rendah, proses ekskresi kalium yang berlebih, dan gangguan pada trancellular shift akan menyebabkan kadar kalium dalam tubuh lebih rendah dari kadar normal. Kadar kalium yang lebih rendah dari normal ini disebut dengan kondisi hipokalemia yang ditandai dengan kadar kalium kurang dari 3,5mEq/L, sedangkan kondisi hipokalemia berat yang dapat 
mengancam jiwa ditandai dengan kadar kalium kurang dari 2,5mEq/L. ${ }^{2,4,5}$

Kondisi pasien dan kadar kalium sangat menentukan rute pemberian koreksi kalium. Pada kondisi hipokalemia berat tidak memungkinkan untuk dilakukan koreksi peroral. Selain itu, pada kasus yang tidak memungkinkan diberikan suplementasi secara oral, seperti penurunan kesadaran, atau kapasitas saluran cerna yang menurun. Sehingga alternatif pemberian secara intravena merupakan cara yang perlu dipertimbangkan oleh klinisi. ${ }^{2,5,6,7}$

Kejadian hipokalemia cukup sering terjadi. Sebanyak $21 \%$ pasien yang mengalami rawat inap mengalami hipokalemia. Dari pasien rawat inap tersebut, sebanyak $5 \%$ diantaranya mengalami hipokalemia berat. Pada pasien geriatri yang menjalani rawat inap, 5\% diantaranya mengalami hipokalemia dan memerlukan koreksi. ${ }^{8}$

Metode koreksi kalium melalui intravena biasanya diberikan melalui akses vena sentral mengingat sifat iritatif kalium untuk menghindari timbulnya nyeri selama proses koreksi tetapi hal ini bersifat invasif dan memiliki risiko yang besar. Oleh karena itu, akses vena perifer sering menjadi salah satu alternatif pada koreksi cepat kalium. Tetapi perlu diingat jika pemberian drip $\mathrm{KCl}$ sering menimbulkan nyeri pada tempat insersi atau sepanjang jalur pemberian koreksi vena perifer akibat sifat iritatif dari kalium tersebut. ${ }^{6,7,9}$

Nyeri yang dirasakan selama pemberian $\mathrm{KCl}$ melalui akses vena perifer merupakan salah satu penyebab pasien menolak atau meminta untuk dihentikan pemberian koreksi. ${ }^{10}$ Penolakan ini dapat menimbulkan efek yang besar terhadap kondisi pasien atau keberhasilan terapi. Selain itu, rasa nyeri yang pernah dirasakan pasien selama pasien mendapatkan koreksi kalium sering menurunkan kepatuhan pasien selama pasien menjalani perawatan, memperpanjang lama perawatan, dan biaya perawatan. Berdasarkan laporan rencana operasi di RS Akademik UGM, pada kasus operasi orthopedi dan operasi laparotomi, sering ditemukan pasien dengan hipokalemia yang memerlukan koreksi kalium yang tidak akan cepat terkoreksi dengan pemberian peroral, tetapi melalui koreksi intravena banyak pasien yang mengeluhkan nyeri dan menolak melanjutkan koreksi dan memilih dilakukan koreksi peroral. Hal ini sering membuat penundaan waktu operasi, memperpanjang lama rawat inap, dan meningkatkan biaya perawatan pasien. Sehingga perlu penilaian dan manajemen nyeri yang tepat untuk meningkatkan toleransi pasien dalam menjalani proses koreksi kalium.

Mengingat pentingnya pemberian koreksi kalium pada pasien hipokalemia dapat mencegah efek yang mengancam jiwa, klinisi tetap perlu berusaha memberikan koreksi kalium dengan berbagai macam pendekatan untuk mengurangi nyeri sehingga meningkatkan kepatuhan pasien dalam menjalankan terapi. Pendekatan tersebut antara lain, memilih jenis pelarut yang digunakan untuk proses pengenceran, mengatur kecepatan pemberian koreksi, dan pemberian antinyeri intravena tambahan yang diberikan bersamaan dengan proses koreksi. ${ }^{9,11}$ Dari berbagai macam metode yang ada, salah satu cara yang dapat dipilih untuk mengurangi nyeri pada proses pemberian $\mathrm{KCl}$ juga dengan meminimalisir risiko dibandingkan pemberian melalui vena sentral adalah dengan pemberian drip $\mathrm{KCl}$ melalui vena perifer disertai dengan 
pemberian anti-nyeri yang dapat diberikan melalui akses intravena. ${ }^{7,12}$

Beberapa penelitian meneliti mengenai antinyeri yang dapat diberikan bersamaan dengan proses koreksi sehingga dapat mencegah terjadinya nyeri atau mengurangi nyeri yang disebabkan oleh proses koreksi kalium tersebut. Salah satu anti-nyeri yang dapat diberikan adalah lidokain. ${ }^{7,10,12,13,14}$ Lidokain merupakan obat anastesi lokal yang ketika diberikan secara intravena terbukti memberikan efek analgesia, antihiperalgesia, dan juga antiinflamasi. ${ }^{15}$ Lidokain memiliki mekanisme tertentu yang mampu menurunkan eksitasi dari sistem saraf tepi sehingga akan menurunkan proses penghantaran nyeri. ${ }^{11}$ Lidokain dipilih sebab dapat diberikan secara lokal dan melalui akses intravena. Selain itu, lidokain dipilih sebab harganya yang murah, ketersediaan obat, efektivitas, keamanan obat, dan juga farmakokinetik dan farmakodinamik dari lidokain itu sendiri. ${ }^{16,17}$ Dan perlu diketahui, selain sebagai anti-nyeri, lidokain memiliki sifat lain yang juga dapat dimanfaatkan dalam menangani efek samping pemberian koreksi kalium, yaitu antiinflamasi dan memiliki efek samping sistemik yang minimal. ${ }^{13,18}$

Penelitian mengenai pemberian lidokain pada pasien yang mendapatkan koreksi kalium intravena pernah dilakukan sebelumnya. ${ }^{7,10,11}$ Salah satu penelitian mengenai pengunaan lidokain dilakukan oleh Pek et al. (2017). ${ }^{10}$ Penelitian ini menunjukkan jika pemberian lidokain intravena bersamaan dengan proses koreksi cepat kalium pada pasien hipokalemia di instalasi gawat darurat (IGD), dapat mengurangi kejadian nyeri selama proses koreksi. Sayangnya pada penelitian ini, pemberian lidokain dilakukan dengan memberikan $3 \mathrm{ml}$ lidokain 1\% secara bolus sebelum proses koreksi dan tidak dilakukan proses randomisasi dan blinding selama penelitian. ${ }^{10}$ Belum ada penelitian di Indonesia yang menilai efektifitas penggunaan lidokain untuk mengurangi nyeri saat pemberian Kalium intravena. Sehingga penelitian ini dilakukan untuk melihat efektifitas lidokain dalam mengurangi nyeri saat koreksi hipokalemia di ruang rawat inap dan diharapkan dapat meningkatkan keselamatan pasien, mengurangi risiko dan mengurangi biaya dari tindakan invasif (akses vena sentral).

\section{METODE}

Penelitian ini merupakan penelitian uji klinis tersamar ganda untuk menilai efektivitas pemberian lidokain intravena selama proses koreksi kalium dengan drip $\mathrm{KCl}$ melalui akses vena perifer. Populasi terjangkau pada penelitian ini adalah pasien hipokalemia yang di rawat di RS Akademik UGM dari periode Agustus hingga Desember 2018 dan mendapatkan terapi koreksi kalium. Tim peneliti, akan mencatat data dan skala nyeri pasien sebelum, saat, dan akhir proses koreksi. Selama jalannya penelitian, perlakuan yang diberikan kepada pasien tidak akan dibuka, kecuali: (1) timbul efek samping dari perlakuan yang diberikan sehingga pasien tidak dilanjutkan dalam penelitian dan (2) pada akhir penelitian saat analisis data.

Proses randomisasi dilakukan dengan cara menggunakan menggunakan tabel bilangan randomisasi yang berisi urutan alokasi kelompok perlakuan dan kelompok kontrol secara acak. ${ }^{19}$ Berdasarkan perhitungan sampel, sebanyak 42 nomor randomisasi yang telah disesuaikan dengan nomor randomisasi pada tabel bilangan 
kemudian dimasukkan ke dalam amplop.

Pada saat alokasi, pasien dimasukkan ke dalam kelompok kontrol atau perlakuan sesuai dengan urutan pada bilangan random. Perawat bangsal akan memberikan koreksi kalium sesuai dengan urutan tabel randomisasi. Kelompok kontrol adalah kelompok pasien yang mendapatkan koreksi kalium dengan metode pengenceran, pengenceran dilakukan dengan mencampurkan infus $\mathrm{NaCl} \quad 0,9 \%$ sebanyak $75 \mathrm{cc}$ dengan ditambah $\mathrm{KCl}$ $25 \mathrm{mEq}$ sebanyak $25 \mathrm{cc}$ yang diberikan melalui infus pump dengan kecepatan 20cc/jam. Sedangkan kelompok perlakuan adalah kelompok yang mendapatkan tambahan lidokain 40mg sebanyak 2cc yang diberikan bersamaan dengan drip KCL.

Berdasarkan penelitian yang dilakukan Lim et al., insidensi terjadinya nyeri pada pasien yang tidak mendapatkan lidokain sebesar $85,7 \%$ dibandingkan dengan $28,6 \%$ pada pasien yang mendapatkan lidokain, berdasarkan perhitungan sampel proporsi 2 kelompok, dengan nilai $\alpha=0,05$ dan $\beta=0,02$, maka didapatkan besar sampel untuk masingmasing kelompok sebesar 14 pasien. ${ }^{4}$ Sampel pada penelitian ini adalah sebesar 42 pasien hipokalemia yang memenuhi kriteria inklusi dan eksklusi, dengan 21 pasien masuk ke dalam kelompok perlakuan dan 21 pasien masuk ke dalam kelompok kontrol.

Pada penelitian ini terdapat dua variabel bebas, yakni pemberian drip $\mathrm{KCl}$ dengan proses pengenceran ditambah dengan lidokain (kelompok subjek) dan pemberian drip $\mathrm{KCl}$ hanya dengan pengenceran saja (kelompok kontrol). Kriteria Inklusi dari penelitian ini, yakni: (1) pasien dengan kadar kalium $<3,5 \mathrm{mmol} / \mathrm{L}$ yang memerlukan koreksi;
(2) berusia antara 18 hingga 60 tahun; (3) tidak ada nyeri pada tempat insersi sebelum dilakukan koreksi atau nilai numeric pain rating scale (NPRS) sebelum koreksi 0; (4) sadar penuh; dan (5) bersedia ikut dalam penelitian dan menandatangani lembar persetujuan setelah mendapatkan penjelasan (informed consent). Sedangkan kriteria eksklusi dari penelitian ini, yakni: (1) konsumsi analgetik sebelum dilakukan koreksi; (2) pasien dengan riwayat alergi terhadap lidokain; (3) pasien dengan riwayat epilepsi atau kejang; dan (4) pasien dengan akses vena yang buruk.

Penelitian ini dilakukan setelah mendapatkan persetujuan dari komisi etik. Penelitian dilakukan dengan cara sebagai berikut: (1) Pasien hipokalemia yang memerlukan koreksi diikutkan ke dalam penelitian setelah menandatangi lembar informed consent. (2) Pasien dialokasikan ke dalam kelompok kontrol dan perlakuan secara random. (3) Pencatatan nyeri dilakukan dengan menggunakan NPRS pada pertengahan proses koreksi, yakni 2,5 jam dari dimulainya koreksi dan pada akhir koreksi (5 jam); (4) Jika saat penilaian muncul nyeri dengan skala $>7$, area ekstremitas yang terasa nyeri diberi kompres dingin dan dielevasi, jika skala nyeri berkurang koreksi tetap dilanjutkan dengan kecepatan dipertahankan 20cc/jam. Jika nyeri timbul kembali, kecepatan drip diturunkan menjadi 10cc/jam hingga selesai. Tetapi jika skala nyeri $>7$ dan menetap, koreksi kalium dihentikan. Jika masih diperlukan koreksi kalium, koreksi dilanjutkan pada jalur vena yang lain dan kecepatan koreksi diturunkan; (5) Jika muncul efek samping lain maka proses blinding dibuka untuk mengetahui jenis intervensi yang diberikan kepada pasien dan pasien tidak dilanjutkan dalam penelitian. Jika 
muncul reaksi alergi diberikan difenhidramine $10 \mathrm{mg}$ dan dexametason $5 \mathrm{mg}$. Jika terjadi efek samping kejang, dapat diberikan diazepam 0,2$0,5 \mathrm{mg} / \mathrm{kgBB}$ bolus lambat.

Seluruh data akan dianalaisis menggunkan SPSS versi 21. Uji bivariat pada variabel dengan skala numerik akan dianalisis menggunakan uji-T apabila berdistribusi normal, atau mann-whitney apabila tidak berdistribusi normal. Uji bivariat pada variabel dengan skala kategorik dan ordinal akan dianalisis dengan uji Chi-square atau fisher-exact. Kekuatan pengaruh intervensi akan disajikan dengan risiko relatif (RR) dengan rentang kepercayaan sebesar $95 \%$.

Dalam penelitian ini, klasifikasi nyeri dibagi ke dalam 3 kelompok, yakni "tidak nyeri" jika skala NPRS sama dengan 0 , "nyeri ringan sedang" jika skala NPRS 1-5, dan "nyeri berat" jika skala NPRS $>5$. Sedangkan progresivitas nyeri dari awal koreksi hingga 2,5 jam dan 2,5 jam hingga akhir koreksi dibedakan menjadi mengalami perburukan nyeri dan tidak mengalami perburukan nyeri.
HASIL

Penelitian ini melibatkan 42 pasien hipokalemia yang memerlukan koreksi kalium dan dirawat di RS Akademik UGM dari bulan Agustus hingga Desember 2018. Selama perjalanan penelitian 5 pasien pada kelompok kontrol mengalami nyeri berat, pasien menolak untuk dilakukan intervensi untuk mengurangi nyeri dan menolak untuk melanjutkan proses koreksi dengan drip $\mathrm{KCl}$. Proses koreksi tetap dilakukan dengan cara pemberian suplementasi kalium peroral dan dropped out dari penelitian. Dari 37 pasien yang tersisa kemudian dilakukan analisis lebih lanjut (Grafik 1).

Uji homogenisitas pada kedua kelompok penelitian terlihat pada Tabel 1. Dapat diketahui karakteristik dasar pasien yang meliputi usia, jenis kelamin, status perkawinan, status pekerjaan, tingkat pendidikan, IMT, tempat dilakukan insersi, kadar kalium sebelum dikoreksi, ukuran abocath, dan hari pemasangan IV line secara stastistik tidak bermakna antara kelompok perlakuan dan kelompok kontrol $(p>0,05)$. Hal ini menunjukkan bahwa kedua kelompok homogen satu sama lain sehingga bias di awal penelitian dapat diminimalisir.

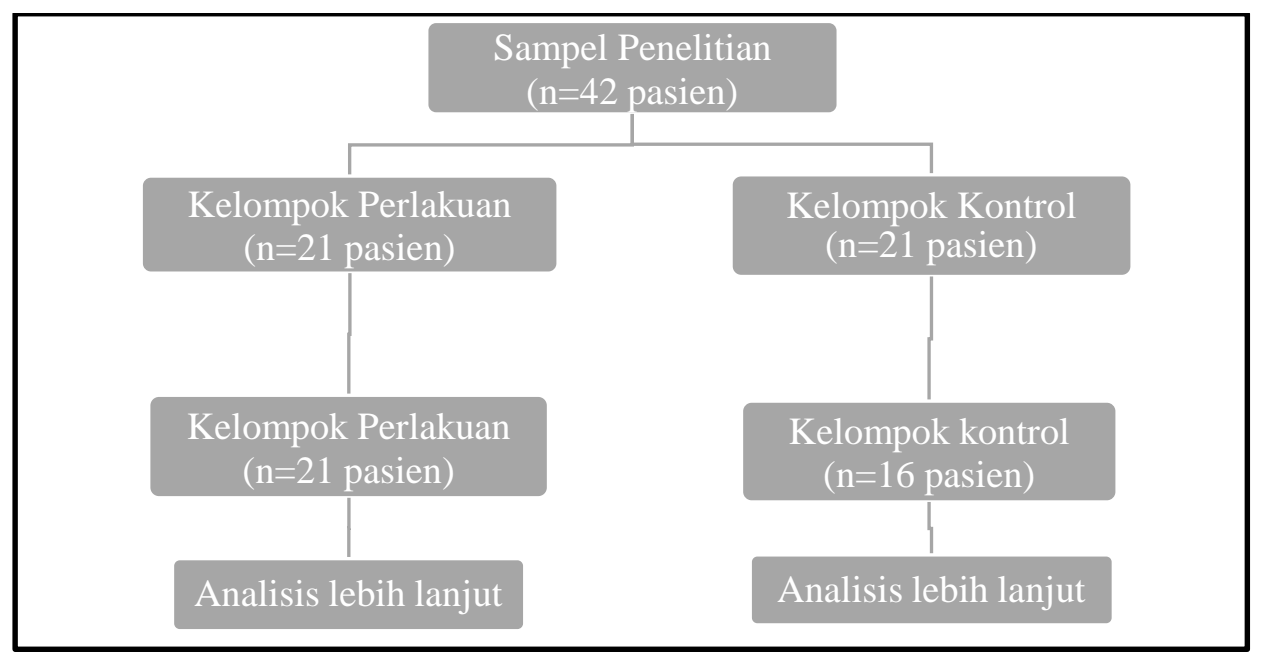

Grafik 1. Proses alokasi kelompok penelitian dan dropped out (DO)

Volume 12, Nomor 1, Tahun 2020 
Tabel 1. Uji homogenitas karakteristik dasar dari 2 kelompok

\begin{tabular}{|c|c|c|c|}
\hline \multirow{2}{*}{ Variabel } & Kelompok Perlakuan & Kelompok Kontrol & \multirow[b]{2}{*}{$\mathrm{p}$} \\
\hline & Rerata \pm SD; $\mathrm{n}(\%)$ & Rerata $\pm \mathrm{SD} ; \mathrm{n}(\%)$ & \\
\hline Usia* & $47,52 \pm 12,44$ & $48,81 \pm 13,62$ & 0,744 \\
\hline \multicolumn{4}{|l|}{ Jenis Kelamin** } \\
\hline a. Laki-laki & $10(71,40 \%)$ & $4(28,60 \%)$ & \multirow{2}{*}{0,16} \\
\hline b. Perempuan & $11(47,80 \%)$ & $12(52,20 \%)$ & \\
\hline \multicolumn{4}{|l|}{ Status Perkawinan** } \\
\hline a. Menikah & $16(59,3 \%)$ & $11(40,7 \%)$ & \multirow{3}{*}{0,88} \\
\hline b. Tidak Menikah & $2(50,00 \%)$ & $2(50,0 \%)$ & \\
\hline c. Janda/duda & $3(50,0 \%)$ & $3(50,0 \%)$ & \\
\hline \multicolumn{4}{|l|}{ Status Pekerjaan** } \\
\hline a. Bekerja & $11(52,4 \%)$ & $10(47,6 \%)$ & \multirow{2}{*}{0,538} \\
\hline b. Tidak Bekerja & $10(62,5 \%)$ & $6(37,5 \%)$ & \\
\hline \multicolumn{4}{|l|}{ Indeks Masa Tubuh (IMT)** } \\
\hline a. Underweight & $3(100,00 \%)$ & $0(0,00 \%)$ & \multirow{5}{*}{0,173} \\
\hline b. Normal & $8(61,5 \%)$ & $5(38,5 \%)$ & \\
\hline c. Overweight & $6(54,5 \%)$ & $5(45,5 \%)$ & \\
\hline d. Pre-obese & $4(57,1 \%)$ & $3(42,9 \%)$ & \\
\hline e. Obese tipe 1 & $0(0,00 \%)$ & $3(100,0 \%)$ & \\
\hline \multicolumn{4}{|l|}{ Tempat dilakukan insersi } \\
\hline a. Tangan kanan & $11(55,00 \%)$ & $9(45,00 \%)$ & \multirow{4}{*}{0,41} \\
\hline b. Tangan kiri & $8(57,10 \%)$ & $6(42,90 \%)$ & \\
\hline c. Kaki kanan & $0(0,00 \%)$ & $1(100,00 \%)$ & \\
\hline d. Kaki kiri & $2(100,00 \%)$ & $0(0,00 \%)$ & \\
\hline Kadar kalium sebelum koreksi* & $2,94 \pm 0,47$ & $3,02 \pm 0,34$ & 0,33 \\
\hline Ukuran Abocath* & $20,19 \pm 1,89$ & $19,63 \pm 1,67$ & 0,63 \\
\hline Hari pemasangan IV line* & $1,10 \pm 1,04$ & $1,25 \pm 0,93$ & 0,76 \\
\hline
\end{tabular}

*Levene's Test ** Uji Chi Square, bermakna jika $\mathrm{p}<0,05$

Banyak penelitian yang melaporkan jika nyeri yang dirasakan oleh pasien tidak hanya semata-mata persepsi tidak nyaman yang dirasakan oleh tubuh, tetapi usia, jenis kelamin, letak pemasangan abocath, ukuran abocath, dan lama abocath sudah terpasang juga akan berpengaruh terhadap sensasi nyeri yang ditimbulkan. Pada penelitian ini semua faktor yang dapat berpengaruh terhadap sensasi nyeri yang timbul selama proses koreksi dianalisis lebih lanjut dalam analisis bivariate (Tabel 2 dan 3).

Pada Tabel 2 dan Tabel 3 terlihat bahwa baik umur, jenis kelamin, ukuran abocath, lama atau hari pemasangan abocath, dan tempat insersi abocath tidak berpengaruh secara statistik terhadap kejadian nyeri pada pasien yang menjalani koreksi kalium, baik pada 2,5 jam sejak dimulainya koreksi hingga 5 jam sejak dilakukan koreksi, hal ini terlihat dari nilai $\mathrm{p}>0,05$.

Sedangkan pada Tabel 4 dan 5, didapatkan jika pemberian lidokain berpengaruh terhadap derajat nyeri yang ditimbulkan dari proses koreksi kalium ini. Terlihat pada 2,5 jam didapatkan lebih banyak pasien yang tidak mengalami nyeri pada kelompok perlakuan (13 pasien) dibandingkan dengan kelompok kontrol sebanyak (3 pasien) bahkan lebih banyak pasien mengalami nyeri pada kelompok kontrol (13 pasien) dibanding kelompok 
perlakuan (8 pasien) dengan 3 pasien dikelompok kontrol mengalami nyeri berat. Pada penilaian di akhir koreksi didapatkan lebih banyak pasien tidak mengalami nyeri pada kelompok perlakuan (13 pasien) dibandingkan kelompok kontrol (4 pasien), selain itu lebih banyak pasien mengalami nyeri pada kelompok kontrol (12 pasien) dibandingkan kelompok perlakuan (8 pasien) dengan 3 pasien dikelompok kontrol mengalami nyeri berat. Hal tersebut menunjukkan superioritas intervensi pemberian lidokain untuk mengurangi kejadian nyeri.

Tabel 2. Analisis bivariat faktor-faktor yang mempengaruhi nyeri pada 2,5 jam

\begin{tabular}{|c|c|c|c|c|}
\hline Parameter & Tidak Nyeri & Nyeri Ringan-Sedang & Nyeri Berat & $p$ \\
\hline $\begin{array}{l}\text { Umur* } \\
(\text { rerata } \pm \text { SD) }\end{array}$ & $44,88 \pm 14,68$ & $49,94 \pm 9,05$ & $54,00 \pm 21,70$ & 0,35 \\
\hline \multicolumn{5}{|l|}{ Jenis kelamin $(\mathrm{n}, \%)^{* *}$} \\
\hline Laki-Laki & $7(50,00 \%)$ & $5(35,7 \%)$ & $2(14,3 \%)$ & \multirow[t]{2}{*}{0,36} \\
\hline Perempuan & $9(39,1 \%)$ & $13(56,5 \%)$ & $1(4,3 \%)$ & \\
\hline $\begin{array}{l}\text { Ukuran Abbocath*** } \\
\text { (Median; range) }\end{array}$ & $20(18-24)$ & $19(18-22)$ & 0 & 0,44 \\
\hline $\begin{array}{l}\text { Hari Pemasangan*** } \\
\text { (Median;range) }\end{array}$ & $1(0-4)$ & $1(0-2)$ & $2(1-3)$ & 0,29 \\
\hline \multicolumn{5}{|l|}{ Tempat Insersi $(\mathrm{n}, \%)^{* *}$} \\
\hline Tangan & $15(44,1 \%)$ & $16(47,1 \%)$ & $3(8,8 \%)$ & 0,76 \\
\hline Kaki & $1(33,3 \%)$ & $2(66,7 \%)$ & $0(0,00 \%)$ & \\
\hline
\end{tabular}

*Uji Annova; ** Chi Square; ***Uji Kruskal Wallis

Tabel 3. Analisis bivariat faktor-faktor yang mempengaruhi nyeri pada 5 jam

\begin{tabular}{|c|c|c|c|c|}
\hline Parameter & Tidak Nyeri & Nyeri Ringan-Sedang & Nyeri Berat & $p$ \\
\hline $\begin{array}{l}\text { Umur* } \\
(\text { rerata } \pm \text { SD) } \\
\text { Jenis kelamin }(n, \%)^{* *}\end{array}$ & $48,29 \pm 11,86$ & $46,82 \pm 12,68$ & $54,00 \pm 21,70$ & 0,48 \\
\hline $\begin{array}{l}\text { Laki-Laki } \\
\text { Perempuan }\end{array}$ & $\begin{array}{c}7(50,00 \%) \\
10(43,50 \%)\end{array}$ & $\begin{array}{l}5(35,70 \%) \\
12(52,2 \%)\end{array}$ & $\begin{array}{c}2(14,30 \%) \\
1(4,3 \%)\end{array}$ & 0,44 \\
\hline $\begin{array}{l}\text { Ukuran Abbocath*** } \\
\text { (Median; range) }\end{array}$ & $20(18-24)$ & $18(18-22)$ & 0 & 0,42 \\
\hline $\begin{array}{l}\text { Hari Pemasangan*** } \\
\text { (Median;range) } \\
\text { Tempat Insersi }(\mathrm{n}, \%)^{* *}\end{array}$ & $1(0-4)$ & $1(0-2)$ & $2(1-3)$ & 0,29 \\
\hline $\begin{array}{l}\text { Tangan } \\
\text { Kaki }\end{array}$ & $\begin{array}{c}16(47,1 \%) \\
1(33,3 \%)\end{array}$ & $\begin{array}{l}15(44,1 \%) \\
2(66,7 \%)\end{array}$ & $\begin{array}{c}3(8,8 \%) \\
0(0,00 \%)\end{array}$ & 0,71 \\
\hline
\end{tabular}

*Uji Annova; ** Chi Square; ***Uji Kruskal Wallis

Tabel 4. Perbandingan derajat nyeri kelompok subjek dan kelompok kontrol pada 2,5 jam

\begin{tabular}{lcccc}
\hline Kelompok & Tidak Nyeri & Nyeri Ringan-Sedang & Nyeri Berat & $\mathrm{p}$ \\
\hline Perlakuan* & $13(61,90 \%)$ & $8(38,10 \%)$ & $0(0 \%)$ & \multirow{2}{*}{$0,01^{* *}$} \\
Kontrol* $^{*}$ & $3(18,75 \%)$ & $10(62,50 \%)$ & $3(18,75 \%)$ & \\
\hline
\end{tabular}

*Uji Chi Square, **bermakna jika $\mathrm{p}<0,05$ 
Tabel 5. Perbandingan derajat nyeri kelompok subjek dan kelompok kontrol pada 5 jam

\begin{tabular}{lcccc}
\hline Kelompok & Tidak Nyeri & Nyeri Ringan-Sedang & Nyeri Berat & $p$ \\
\hline Perlakuan* & $13(61,90 \%)$ & $8(38,10 \%)$ & $0(0 \%)$ & \multirow{2}{*}{$0,03^{* *}$} \\
Kontrol* & $4(25,00 \%)$ & $9(56,25 \%)$ & $3(18,75 \%)$ & \\
\hline
\end{tabular}

*Uji Chi Square, **bermakna jika $\mathrm{p}<0,05$

Selama proses koreksi kalium, progresivitas nyeri juga sangat diperhatikan selain kemunculan nyeri. Progresivitas nyeri dibandingkan baik antara awal sebelum dilakukan koreksi dengan pertengahan proses koreksi $(2,5$ jam) dan antara pertengahan proses koreksi $(2,5$ jam) dengan akhir proses koreksi (5 jam).

Dari Tabel 6, diketahui jika dari awal proses koreksi hingga 2,5 jam, pemberian lidokain intravena, dapat mencegah kejadian atau progresivitas nyeri hingga 53\% dibandingkan dengan kelompok kontrol $(\mathrm{RR}=0,57,95 \% \mathrm{IK}$ 0,26-0,85) dan bermakna secara statistik $(p=0,01)$. Tetapi dari pertengahan hingga akhir, lidokain tidak mampu mengangani progresivitas nyeri (Tabel 7). Progresivitas nyeri pada kelompok perlakuan 5\% lebih rendah dibandingkan kelompok kontrol $(\mathrm{RR}=0,95,95 \%$ IK $0,30-2,99)$ tetapi tidak bermakna secara statistik $(p>0,05)$.

Tabel 6. Progresivitas nyeri dari awal penelitian hingga pertengahan proses koreksi (2,5 jam)

\begin{tabular}{lcccc}
\hline \multicolumn{1}{c}{ Kelompok } & Muncul Nyeri & $\begin{array}{c}\text { Tidak Muncul } \\
\text { Nyeri }\end{array}$ & RR (95\% IK) & $\mathrm{p}$ \\
\hline Perlakuan* & $8(38,10 \%)$ & $13(61,90 \%)$ & 0,47 & 0 \\
Kontrol* & $13(81,25 \%)$ & $3(18,75 \%)$ & $(0,26-0,85)$ & $0,01^{* *}$ \\
\hline
\end{tabular}

*Uji Chi Square, **bermakna jika $\mathrm{p}<0,05$

Tabel 7. Progresivitas nyeri dari pertengahan proses koreksi (2,5 jam) hingga akhir proses

\begin{tabular}{lcccc}
\multicolumn{5}{c}{ koreksi (5 jam) } \\
\hline \multicolumn{1}{c}{ Kelompok } & Muncul Nyeri & $\begin{array}{c}\text { Tidak Muncul } \\
\text { Nyeri }\end{array}$ & RR (95\% IK) & p \\
\hline Perlakuan* & $5(23,81 \%)$ & $16(76,19 \%)$ & 0,95 & 0,99 \\
Kontrol* & $1(6,25 \%)$ & $15(93,75 \%)$ & $(0,30-2,99)$ & \\
\hline
\end{tabular}

*Uji Chi Square, bermakna jika $\mathrm{p}<0,05$

\section{PEMBAHASAN}

Dari penelitian-penelitian yang sudah dilakukan mengenai persepsi nyeri, ada faktor-faktor yang berpengaruh pada persepsi seorang pasien, antara lain jenis kelamin dan usia. ${ }^{10,21,21}$ Pada penelitian ini juga dikaji mengenai pengaruh usia dan jenis kelamin terhadap derajat nyeri yang dirasakan pasien, tetapi hasil penelitian ini menunjukkan jika kedua faktor ini tidak berpengaruh terhadap derajat nyeri $(p>0,05)$. Selain itu, berdasarkan pedoman mengenai pemasangan kateter intravena perifer, perlu diperhatikan dalam pemilihan ukuran, pemilihan tempat pemasangan kateter, dan hari pemasangan kateter, sebab hal ini akan berpengaruh terhadap jenis terapi yang akan diberikan dan komplikasi yang akan muncul, seperti flebitis atau pun sensasi nyeri. ${ }^{13}$ Oleh karena itu, pada penelitian ini juga dikaji 
mengenai 3 faktor tersebut terhadap derajat nyeri yang dirasakan pasien selama menjalani proses koreksi sehingga akan meminimalisir bias apakah nyeri tersebut disebabkan oleh penentuan 3 faktor tersebut ataukah disebabkan oleh perlakuan yang diberikan. Hasil penelitian menunjukkan jika ketiga faktor tersebut tidak berpengaruh terhadap kejadian nyeri baik pada kelompok perlakuan ataupun kelompok kontrol $(\mathrm{p}>0,05)$, sehingga dapat dipastikan jika faktor-faktor lain tidak akan menimbulkan bias terhadap luaran nyeri yang akan dinilai selama proses koreksi kalium.

Penyebab pasti mengenai etiologi munculnya nyeri selama proses koreksi kalium belum diketahui secara jelas. Tetapi terdapat satu teori yang beranggapan bahwa $\mathrm{KCl}$ merupakan agen non-neoplastik yang memiliki sifat iritatif, sifat iritatif dari $\mathrm{KCl}$ ini akan menyebabkan iritasi terhadap epitelium sel endothel pembuluh. Sifat iritatif ini ditimbulkan oleh sifat dari bahan kimia $\mathrm{KCl}$ itu sendiri, $\mathrm{pH}$, dan osmolaritas dari $\mathrm{KCl}$. Jika proses koreksi dilakukan pada pembuluh darah perifer, maka agen iritatif ini akan menimbulkan sensasi nyeri pada tempat pemasangan akses intravena atau sepanjang dari jalur intravena. $^{7,12,14}$

Lidokain dapat memberikan efek antinyeri dimulai 5 hingga 20 menit dari sejak pemberian dan bertahan hingga 5 jam dari sejak pemberian. Pemberian secara intravena dan dilakukan dengan drip sering dipilih oleh klinisi, sebab dengan pemberian secara intravena akan mempertahankan kadar lidokain dalam darah sehingga akan memaksimalkan dari efek analgetik yang diberikan dari lidokain tersebut. $^{16,22}$
Dari penelitian-penelitian sebelumnya, terbukti jika lidokain dapat mengurangi kejadian nyeri selama proses koreksi. ${ }^{7,8,10}$ Pada penelitian yang dilakukan Pek et al., dilaporkan pemberian lidokain selama proses koreksi kalium secara signifikan mengurangi kejadian nyeri $(\mathrm{RR}=0,42$, 95\% IK 0,20-0,87, p=0,013). ${ }^{10}$ Hal yang sama juga terlihat pada penelitian ini, baik pada pertengahan proses koreksi (2,5 jam) dan akhir koreksi (5 jam), pemberian lidokain intravena dapat mengurangi kejadian nyeri yang timbul selama proses koreksi. Lidokain dan metabolit aktifnya berinteraksi dengan cara memblokade gerbang natrium sehingga menghambat masuknya natrium. Natrium yang tidak dapat masuk akan menginhibisi terjadinya proses depolarisasi pada susunan saraf perifer sehingga menurunkan impuls ektopik dari sel-sel saraf aferen dan menghambat refleks polisinaptik kornu dorsalis di medula spinalis yang akan menghambat penghantaran impuls nyeri tanpa terjadi blokade konduksi normal. ${ }^{11,18}$

Pada kelompok perlakuan, terlihat semua pasien dapat menyelesaikan proses koreksi hingga akhir penelitian. Derajat nyeri yang muncul pada pasien perlakuan tidak ada yang mencapai nyeri derajat berat. Terdapat 8 pasien mengalami nyeri ringan-sedang tetapi nyeri masih dalam batas yang dapat ditolerir pasien dan semua pasien tetap dapat menyelesaikan hingga akhir proses koreksi. Semua pasien yang masuk ke dalam kelompok perlakuan mengalami perbaikan kadar kalium setelah proses koreksi, sebagian besar pasien langsung mencapai kadar normokalemia, hanya sedikit pasien yang tidak mencapai normokalemia disebabkan karena pasien mengalami hipokalemia berat dan perlu memerlukan beberapa serial koreksi 
kalium. Dari literatur yang ada, belum ditemukan mengenai interaksi antara pemberian kalium dan lidokain baik diberikan secara terpisah atau drip, sehingga dengan melihat hasil koreksi, nyeri yang ditimbulkan, dan tidak adanya efek samping yang terjadi selama proses koreksi pada kelompok perlakuan, pemberian lidokain aman dalam menghilangkan nyeri selama proses koreksi dan proses koreksi tetap efektif dalam memperbaiki kadar kalium pada pasien hipokalemia. ${ }^{23,24}$

Selain itu progresivitas nyeri, juga dinilai dalam penelitian ini. Dari hasil progresivitas nyeri yang ada dengan membandingkan antara awal koreksi hingga pertengahan koreksi dan pertengahan koreksi dengan akhir koreksi, lidokain terlihat mampu dalam mencegah terjadinya progresivitas nyeri dari awal koreksi hingga pertengahan koreksi. Tetapi pada progresivitas nyeri dari pertengahan proses koreksi hingga akhir koreksi terlihat bahwa lidokain tidak bermakna secara statistik dalam mencegah terjadinya progresivitas nyeri.

Pada penelitian ini digunakan dosis rendah lidokain dalam mengatasi nyeri akibat proses koreksi. Penelitian ini juga mengkombinasikan antara proses pengenceran dan pengaturan kecepatan proses koreksi, yakni $20 \mathrm{cc} / \mathrm{jam}$ atau $10 \mathrm{cc} / \mathrm{jam}$ untuk mengoptimalkan dari efek antinyeri lidokain. Lidokain terbukti bermanfaat dalam mengatasi nyeri yang bersifat akut tetapi lidokain sebagai antinyeri sangatlah bersifat dose dependent, artinya kemampuan lidokain dalam mengatasi nyeri sangat bergantung pada dosis lidokain yang diberikan. Penelitian sebelumnya menyebutkan jika pada nyeri-nyeri dengan intensitas yang lebih berat akan memerlukan pengaturan dosis dan akan memerlukan dosis yang lebih besar untuk dapat mengatasi nyeri. ${ }^{25,26,27,28}$ Sehingga saat nyeri tetap muncul, klinisi perlu mengevaluasi dari dosis lidokain yang diberikan. Progresivitas nyeri yang dirasakan pasien, dapat ditanggulangi dengan menaikkan dosis lidokain yang diberikan. Tetapi perlu diingat, dalam menaikkan dosis pemberian lidokain perlu dengan pengawasan terhadap efek sistemik lain yang dapat muncul, seperti efek pada kardiovaskular. ${ }^{29}$ Klinisi wajib memastikan dosis pemberian lidokain yang mampu menanggulangi nyeri tanpa mengesampingkan keamanan dari pemberian lidokain tersebut. ${ }^{25,26}$

Progresivitas nyeri juga dipengaruhi oleh adanya komorbid dan riwayat penggunaan analgesia, dimana hal ini juga perlu untuk dievaluasi dalam manajemen nyeri pasien. Komorbid dan riwayat penggunaan analgesia sering berpengaruh terhadap ambang nyeri pasien. Gagal ginjal dan diabetes sering menyebabkan terjadinya hipokalemia. ${ }^{6}$ Pasien dengan gagal ginjal yang menjalani hemodialisis rutin dan pasien diabetes akan lebih mudah merasakan nyeri dibandingkan dengan pasien tanpa komorbid lain. ${ }^{30,31}$ Riwayat penggunaan analgesia juga akan berpengaruh terhadap ambang nyeri dan respon terhadap pemberian antinyeri. ${ }^{32}$ Penurunan ambang nyeri akibat adanya komorbid atau riwayat penggunaan analgesia sebelumnya akan berpengaruh terhadap respon awal pemberian antinyeri dan progresivitas nyeri. Saat tidak berespon dengan dosis secara umum, nyeri yang dirasakan pasien tidak akan teratasi dan terus berkembang. Pentingnya evaluasi komorbid dan riwayat penggunaan analegesia akan sangat berpengaruh terhadap besar dosis yang diberikan dalam menghilangkan nyeri maupun mencegah progresivitas. 
Selain itu, perlu diingat jika efek nyeri yang ditimbulkan dari $\mathrm{KCl}$ tidak hanya disebabkan oleh sifat iritatif dari $\mathrm{KCl}$, tetapi bisa juga disebabkan oleh adanya flebitis, trombosis, infiltrasi, atau ekstravasasi dari $\mathrm{KCl}$ selama proses koreksi. 7,12,33,34 Jika memang sebab lain ini terbukti menyebabkan munculnya nyeri atau progresivitas nyeri yang terjadi selama proses koreksi, tentu klinisi wajib untuk melakukan suatu pendekatan sesuai dengan kondisi yang mendasari. Sebab dengan mengatasi penyebab dari munculnya nyeri selama proses koreksi akan mampu mengatasi nyeri dan progresivitas nyeri yang terjadi selama proses koreksi. Sehingga klinisi sangat dituntut jeli untuk dapat mengenali dan membedakan penyebab dari munculnya nyeri yang dirasakan pasien tersebut.

Selain itu, nyeri merupakan suatu persepsi tidak nyaman yang diekspresikan oleh pasien itu sendiri. ${ }^{35}$ Perlu diingat jika ambang nyeri dari masing-masing individu akan berbeda satu sama lain dan sangat sulit untuk menilai nyeri secara objektif. ${ }^{36}$ Dalam penelitian ini masih digunakan NPRS yang sangat subjektif dari diri pasien, sehingga sangat diperlukan pemeriksaan dari parameter klinis lain yang lebih bersifat objektif untuk dapat menilai nyeri dan progresivitas nyeri yang dirasakan oleh pasien sebab peningkatkan dosis lidokain akan memerlukan pengawasan terhadap keamanan dan efek lain yang ditimbulkan.

\section{KESIMPULAN}

Hasil penelitian ini memperlihatkan bahwa pemberian lidokain intravena dapat mengurangi kejadian nyeri dari pemberian drip $\mathrm{KCl}$ melalui akses vena perifer. Rasa nyeri yang dialami subjek penelitian dapat diakibatkan kondisi lain diluar pemberian Kalium seperti adanya phlebitis, ekstravasi atau sebab lainnya. Perlu dilakukan penelitian lebih lanjut mengenai peran lidokain dalam mencegah terjadinya progresivitas nyeri selama proses pemberian $\mathrm{KCl}$ dengan sampel yang lebih besar dan dengan alat ukur nyeri dan parameter lain yang lebih bersifat objektif.

\section{DAFTAR PUSTAKA}

1. Tulungne RS, Tamansa GE, Saerang JSM, Rares LM. Jurnal KEDOKTERAN KLINIK (JKK), Volume 1 No 2 , Desember 2016. J Kedokt Klin (JKK), Vol 1 No 2, Desember 2016. 2016;1(katarak):37-45

2. Kardalas E, Paschou SA, Anagnostis P, Muscogiuri G, Siasos G, Vryonidou A. Hypokalemia: a clinical update. Endocr Connect. 2018;7(4):R135-46

3. Palmer BF, Clegg DJ. Physiology and pathophysiology of potassium homeostasis. Adv Physiol Educ. 2016;40(4):480-90

4. Lim S. Approach to hypokalemia. Acta Med Indones [Internet]. 39(1):56-64. Available from: http://www.ncbi.nlm.nih.gov/pubm ed/17297212

5. Weiner D, Wingo CS. Hypokalemia-consequences, causes, and correction. University of Florida College of Medicine, and Gainesville Veterans Administration Medical Center. 1179-1188

6. Viera AJ, Wouk N. Potassium Disorders: Hypokalemia and Hyperkalemia. Am Fam Physician [Internet]. 2015;92(6):487-95. Available from: http://www.ncbi.nlm.nih.gov/pubm ed/26371733

7. Juan CX, Cheng LL. The 
effectiveness of intravenous Lidocaine used to treat pain related to peripheral potassium chloride infusion in adult hospitalized patients: a systematic review protocol. JBI Database Syst Rev Implement Reports. 2014;12(9):124-31

8. Widodo D, Setiawan B, Chen K, Nainggolan L, Santoso WD. The prevalence of hypokalemia in hospitalized patients with infectious diseases problem at Cipto Mangunkusumo Hospital, Jakarta. Acta Med Indones. 2006;38(4):2025

9. Asmar A, Mohandas R, Wingo CS. A Physiologic-Based Approach to the Treatment of a Patient With Hypokalemia HHS Public Access. Am J Kidney Dis [Internet]. 2012;60(3):492-7. Available from: https://www.ncbi.nlm.nih.gov/pmc/ articles/PMC4776048/pdf/nihms39 6447.pdf

10. Pek JH, Tan HC, Seth P, Wong E. Reducing Pain Experienced During Potassium Chloride Infusion in the Emergency Department. Eurasian J Emerg Med. 2017;16(4):148-52

11. Sipahutar TC, Fuadi I, Bisri T. Efek Lidokain Intravena terhadap Nilai Numeric Rating Scale dan Kebutuhan Fentanil Pascaoperasi dengan Anestesi Umum. J Anestesi Perioper. 2014;1(3):167-73

12. Chan R, Armstrong D. Kalium perifert mindre ont i $\mathrm{NaCl}$. 2004;57(1):27-31

13. Diseases Branch C, of Health D. Guideline: Peripheral intravenous catheter (PIVC). 2018;28. Available from:https://www.health.qld.gov.au /data/assets/pdf file/0025/444490/i care-pivc-guideline.pdf

14. John Ashurst, Shane R. Sergent, Benjamin J. Wagner. Evidence-
Based Management Of Potassium Disorders In The Emergency Department. Emerg Med Pract. 2016;18(11)

15. Daykin H. The efficacy and safety of intravenous lidocaine for analgesia in the older adult: a literature review. $\mathrm{Br} \mathrm{J}$ Pain. 2017;11(1):23-31

16. Pucino F, Danielson BD, Carlson JD, Strommen GL, Walker PR, Beck CL, et al. Patient tolerance to intravenous potassium chloride with and without lidocaine. Drug Intell Clin Pharm. 1988;22(9):676-9

17. Lim ETM, Kloo ST, Tweed WA. Efficacy of lignocaine in alleviating potassium chloride infusion pain. Anaesth Intensive Care. 1992;20(2):196-8

18. Weinberg L. Pharmacokinetics and pharmacodynamics of lignocaine: A review. World $\mathrm{J}$ Anesthesiol [Internet]. 2015;4(2):17. Available from:

http://www.wjgnet.com/22186182/full/v4/i2/17.htm

19. Sudigdo S, Ismael S. Dasar-dasar metodologi penelitian klinis $4^{\text {th }} \mathrm{Ed}$. 2011. Jakarta: Sagung Seto

20. Ahmad WL, Ho CC. The Impact of a Patient Education Package on Outcomes of Pain Management Following Orthopaedic Surgery in a Tertiary Hospital in Malaysia. Med Heal [Internet]. 2015;10(1):58-65. Available from: http://journalarticle.ukm.my/8697/1 $/ 8 . \% 2520 \mathrm{Ho} \% 2520 \mathrm{SE} \% 2520 \mathrm{et} \% 2$ 520al.pdf

21. Wandner LD, Scipio CD, Hirsh AT, Torres CA, Robinson ME. The perception of pain in others: how gender, race, and age influence pain expectations. J Pain. 2012; 13(3): 480-90

22. Liu J, Lv X. The pharmacokinetics and pharmacodynamics of 
lidocaine- loaded biodegradable poly(lactic-co-glycolic acid) microspheres. Int $\mathrm{J}$ Mol Sci. 2014;15(10):17469-77

23. Drugs.com. Drug Interaction Between $\mathrm{KCl}$ and Lidocaine. [Internet] 2019. [cited 2019 Dec 09]. Available from: https://www.drugs.com/drug-intera ctions/kcl-with-lidocaine-191214126-1464-0.html

24. Pusat Informasi Obat Nasional Badan Pengawas Obat dan Makanan. Pencarian Interaksi Obat: Lidokain dan KCl. [Internet] 2019. [cited 2019 Dec 09]. Available from:

http://ioni.pom.go.id/ioni/cari/intera ksi-

obat?field_obat_1_value=lidokain \&field_obat_2_value $=$ kalium

25. Weinberg L. Pharmacokinetics and pharmacodynamics of lignocaine: A review. World $\mathrm{J}$ Anesthesiol [Internet]. 2015;4(2):17. Available from:

http://www.wjgnet.com/22186182/full/v4/i2/17.htm

26. de Souza MF, Kraychete DC. The analgesic effect of intravenous lidocaine in the treatment of chronic pain: A literature review. Rev Bras Reumatol [Internet]. 2014;54(5):386-92. Available from: http://dx.doi.org/10.1016/j.rbre.201 4.01 .002

27. Kurabe $M$, Furue $H$, Kohno $T$. Corrigendum: Intravenous administration of lidocaine directly acts on spinal dorsal horn and produces analgesic effect: An in vivo patch-clamp analysis. Sci Rep [Internet]. 2017;7(April):46814. Available from: http://dx.doi.org/10.1038/srep2625 3
28. Yousefshahi F, Predescu O, Asenjo JF. The efficacy of systemic lidocaine in the management of chronic pain: A literature review. Anesthesiol Pain Med. 2017;7(3)

29. Torp KD, Simon LV. Lidocaine Toxicity. 2019. StatPerls Publishing LLC

30. Telly O, Cavlak U. Measuring the pain threshold and tolerance using electrical stimulation in patients with type II diabetes mellitus. Journal of Diabetes and Its Complications. 2006; 20(5): 308316

31. Upadhyay C, Cameron K, Murphy L, Battistella M. Measuring pain in patients undergoing hemodialysis: A review of pain assessment tools. Clin Kidney J. 2014;7(4):367-72

32. Müller M, Kamping S, Benrath J, Skowronek H, Schmitz J, Klinger R, Flor H. Treatment history and placebo responses to experimental and clinical pain in chronic pain patients. European Journal of Pain. 2016; 20(9): 1530-1541

33. Journal I, Studies N, Katip I, Universitesi C, Work AM, On NOG, et al. Extravasations of Vesicant / Non- Vesicant Drugs and Evidence - Based Management. 2014;(January 2012)

34. Lafreniere JA, Hamilton DP, Carr RR. Assessing the guidelines for potassium replacement in pediatric oncology patients receiving amphotericin B. J Pediatr Pharmacol Ther. 2006;11(4):223-22332

35. Fink R. Pain Assessment: The Cornerstone to Optimal Pain Management. Baylor Univ Med Cent Proc. 2000;13(3):236-9

36. Philpott L. Beating pain. Aust J Pharm. 2014;95(1126):42-6 